\title{
Bio-based Methods with Potentials for Application in Wooden Furniture Industry
}

\section{Biološke metode s potencijalom za primjenu u proizvodnji namještaja od drva}

Review paper • Pregledni rad Received-prispjelo: 4. 2. 2019 Accepted-prihvaćeno: 28. 4. 2020. UDK: $630 * 836.1$

https://doi.org/10.5552/drvind.2020.1903
C 2020 by the author(s). Licensee Faculty of Forestry, University of Zagreb. This article is an open access article distributed under the terms and conditions of the Creative Commons Attribution (CC BY 4.0) license.

\begin{abstract}
Furniture market is shifting towards green and innovative products. The use of bio-based methods in wooden furniture industry presents a big potential for the development of materials with new characteristics, of unique furniture items, and can reduce the environmental impact. Bio-based methods can be used for wood protection and decoration, fibre board production, and development of new wooden materials, such as wood hybrids and functionalised wood. The bio-based methods, investigated for their potentials in wood industry, include the use of living organisms, natural products, and biomimicry. Despite ongoing developments there are still major drawbacks associated with many of these technologies: unreliability and inadequate efficiency of the methods, inadequate mechanical properties or dimensional stability of the final products, and high costs. Thus, further developments are needed. In this review, we present the existing and arising bio-based methods with potential in wooden furniture production. Furthermore, we shortly present their marketing potential.
\end{abstract}

Key words: biotechnology; natural products; wood; furniture; wood protection; wood colouring; natural adhesives; wood functionalisation; biomimicry

SAŽETAK • Tržište namještaja sve se više pomiče prema zelenim i inovativnim proizvodima. Primjena bioloških metoda u proizvodnji namještaja od drva znači velik potencijal za razvoj materijala novih svojstava te za proizvodnju jedinstvenih predmeta namještaja. Osim toga, uvođenje bioloških metoda u industriju namještaja može pridonijeti i smanjenju štetnog utjecaja na okoliš. Biološke se metode mogu primijeniti u zaštiti i dekoraciji drva, u proizvodnji ploča vlaknatica $i$ u razvoju novih drvnih materijala kao što su drvni hibridi i funkcionalizirano drvo. Spomenute metode, čiji se potencijal primjene u proizvodnji namještaja istražuje, uključuju biotehnologiju, uporabu prirodnih proizvoda i biomimikriju. Unatoč stalnom razvoju, još postoje znatni nedostatci povezani s primjenom tih tehnologija. To su složenost ili nepouzdanost metoda, neadekvatna mehanička svojstva ili dimenzijska stabilnost konačnih proizvoda te visoki proizvodni troškovi. Stoga je potrebno i dalje razvijati te metode radi njihove primjene u proizvodnji namještaja. U ovom su radu predstavljene razvijene biološke metode $i$ one koje su u fazi razvoja a imaju potencijala za primjenu u proizvodnji namještaja od drva. Usto je ukratko opisan i njihov marketinški potencijal.

Ključne rïječi: biotehnologija; prirodni proizvodi; drvo; namještaj; zaštita drva; bojenje drva; prirodna ljepila; funkcionalizacija drva; biomimikrija

\footnotetext{
Author is a graduate of Biotechnology at Biotechnical Faculty, University of Ljubljana, Ljubljana, Slovenia.

2 Author is professor at Faculty of Design, Independent Higher Education Institute, Associated Member of University of Primorska, Trzin, Slovenia.
} 


\section{INTRODUCTION}

\section{UVOD}

Furniture production represents a big market (International Wooden Furniture Markets: A review, 2004; Wang et al., 2016), which requires design of original products to move up the value chain. This, among others, includes upgrades of the manufacturing processes and of the final product (International..., 2004). Such original products can be designed with the use of innovative bio-based technologies.

Wood biotechnology and the use of natural products in wooden furniture industry have long history and are still being developed. They have potential for development of materials with new characteristics, unique furniture items, and can help to reduce the environmental impact (Burgert et al., 2015; Mai et al., 2004; Robinson et al., 2012). Applications based on organisms and their products with potential in wood industry can be classified into three categories: 1) biotechnological use of live organisms or their enzymes for production of new substance or for catalytic purposes (Mai et al., 2004; Smith, 2009), 2) use of extracts or other non-catalytic products of organisms (Yang, 2009), and 3) biomimicry (Chen et al., 2017; Umorina, 2017).

There are quite a few reviews describing specialised topics of wood biotechnology or the use of natural products in the wood industry. For example, wood protection and fibre board production has been previously described in Mai et al. (2004) and surface functionalisation in Petrič et al. (2013). Furthermore, advanced breeding methods for creation of new tree and wood varieties are gaining importance (Bhalerao et al., 2003). However, the latter is out of the scope of this review as we focus on the processing of wood for production of furniture. Moreover, we failed to find a general overview of methods based on live organisms or their products used in wood processing. Thus, we review developed and arising methods based on live organisms or their products with potential in wooden furniture industry. Our main focus is on the methods that have not yet been widely applied in the industry. We also briefly discuss the marketing potential of these technologies.

\section{ADHESIVES AND WOODEN BOARDS 2. LJEPILA I DRVNE PLOČE}

Normally, production of board materials requires the use of high pressure and temperatures as well as toxic chemicals. This is associated with higher costs and adverse environmental effects (Liu et al., 2010; Mai et al., 2004). Thus, more environmentally-friendly techniques are being developed, as described by Ferdosian et al. (2017). This includes both natural adhesives, such as lignin and plant proteins (Ferdosian et $a l ., 2017$ ), and the use of oxidative enzymes or live organisms to increase adhesive properties of wood and catalyse covalent bond formation between adhesives (Mai et al., 2004). Enzymatic systems can be singlecomponent, utilising only oxidative enzymes such as peroxidases or laccases, which are most commonly used enzyme, or two-component with addition of lignin and similar phenolic substances as adhesives. (Mai et al., 2004; Widsten and Kandelbauer, 2008).

Enzymes can be used in pre-treatment of wooden fibres or to aid in the gluing processes. This can reduce the heat and glue content needed to produce mediumdensity fibre boards. The use of enzymes may also contribute to the mechanical properties of the boards (Fackler et al., 2008; Mai et al., 2004). Pre-treatment of fibre particles with laccases increases the self-bonding properties of the fibres surface (Gabrič and Pohleven, 2014). Furthermore, adhesive surface properties can be improved by enzymatic functionalisation. Laccase-catalysed covalent binding of urea to fibres was shown to increase the adhesion. However, this effects was smaller than the effects of board density and glue content (Fackler et al., 2008). Laccase was also tested at the pilot level for catalysis of bonds between lignin molecules already present in the fibre particles. The process is claimed to have a potential, but it is limited by poor dimensional stability of the product and the need for the use of higher temperatures in the processing of boards (Felby et al., 2002). Cost effective production of laccases is also being studied. Laccase producing fungi can be grown on medium where main nutrients are waste materials (Zhou et al., 2014).

The use of lignin as an adhesive has been thoroughly investigated. Lignin can be used to partially substitute phenolic components in synthetic adhesives. Products created with such an adhesive have only slightly reduced strength retention and only slightly higher water uptake (Jin et al., 1990). Lignin can be produced either with wood degradation by brown rot fungi, which is a time consuming process with difficult extraction steps and requires further enzymatic processing of lignin, or from the industrial waste, which contains lignin with reduced adhesive properties (Gabrič and Pohleven, 2014; Jin et al., 1990; Mai et al., 2004). An alternative to lignin adhesives is the use of proteins. A combination of soy proteins and $\mathrm{CaCO}_{3}$ resulted in a glue with good adhesive properties and water resistance (Liu et al., 2010).

\section{WOOD PROTECTION}

\section{ZAŠTITA DRVA}

Wood must be protected against biological and abiotic factors in all stages of furniture production (Yang, 2009). Selection of preservatives depends on the intended use of the wooden material, e.g. indoor or outdoor. Some outdoor protectants can be harmful to human health, leading to respiratory problems and allergies or even serious medical complications. They can also have negative effects on environment, especially at the time of the disposal (Pánek et al., 2014). Examples of traditional preservatives with negative effects on the health are those containing compounds of arsenic, zinc, copper, and creosotic oil. Due to their adverse effects they are often prohibited from the use in furniture industry (Pánek et al., 2014; Schubert et al., 2012). Therefore, new wood protection technolo- 
gies are being developed. Biological protectants can have more targeted mode of action against wood pathogens and are biodegradable. However, they are also more sensitive to degradation and hence require special care (Mai et al., 2004). Another option for protection against pathogens is modification of wood properties, leading to more hydrophobic nature and reduced water content of wood (Burgert et al., 2015; Humar and Lesar, 2013).

\subsection{Protection with microorganisms}

\subsection{Zaštita mikroorganizmima}

Pathogenic organisms cause wood degradation and loss of mechanical properties, unwanted colouring, and production of harmful toxins (Yang, 2009). Due to high humidity in some living spaces, it is necessary to protect wood against pathogenic microorganisms. This can be done with the inoculation of wood with protective non-pathogenic organisms (Bruce \& King, 1991; Mai et al., 2004), as further described by Mai et al. (2004) and Susi et al. (2011). Bio-controlling organisms compete with the pathogens or produce compounds that prevent the growth of pathogens (Mai et al., 2004; Susi et al., 2011). However, protection with microorganisms is not long-lasting, retaining effectiveness only for a few years (Bruce \& King, 1991; Mai et al., 2004). It also has varying results against different fungi and in different environments (Mai et al., 2004). Microbial extracts may improve the reliability of protection under varying conditions (Yang, 2009). However, bio-control fungi only provide preventive protection against the invasive fungi. Thus, it is important to apply the protective organism already during the production of furniture (Bruce \& King, 1991; Mai et al., 2004). On the other hand, application of bacterial and fungal spores on wood already infected by insects has some potential (Mai et al., 2004). Bio-finishes based on black mould and oil are already used in practice (van Nieuwenhuijzen et al., 2016). On the other hand, some bio-controlling organisms will require further research before becoming commercially applicable. These include Streptomyces isolates (Jung et al., 2018) and Bacillus subtilis that can be combined with the application of essential oils (Sajitha et al., 2018; Wang et al., 2012).

Fungi can also be used for increasing the permeability of the outdoors wood to commercial preservatives. However, the technology is still not regarded as economically feasible (Schwarze \& Schubert, 2017; Thaler et al., 2012).

\subsection{Protection with natural products \\ 3.2. Zaštita prirodnim proizvodima}

Natural protectants have a long tradition. Many protectants like resins, extractives, essential oils, and lignin are still being further tested (Fernández-Costas et al., 2017) and some have also been patented (Yang, 2009). Examples include capsaicin containing extract from chilli, extracts from durable wood species containing tannins, flavonoids, and terpenoids, and essential oils containing phenols (Pánek et al., 2014). The application of different extracts for the protection of wood is more thoroughly described in Yang (2009).
The use of natural protectants has various benefits. They can be applied as a protection against organisms from different kingdoms, can be nontoxic to humans, and are produced from renewable sources - organisms, ranging from plants to fungi and bacteria (Pánek et al., 2014; Yang, 2009). Treatment with natural products can change the surface properties of wood and thus reduce the leaching of other protectants (Fernández-Costas et al., 2017). Multifunctional protectants that also serve as dyes have been investigated (Colak, 2016; Ozen et al., 2014). Furthermore, protectants can be extracted from waste materials. An example is bark, which has protective potential due to high content of tannins, resins, and waxes (Yang, 2009). Similarly, lignin, a waste product from paper industry, has potential as protectant due to its phenolic content (Fernández-Costas et al., 2017). Some plant extracts with antifungal properties, such as mimosa and quebracho extracts, are already commercially available (Tascioglu et al., 2013).

However, the use of natural protectants still poses a problem. Their activity can be inconsistent and some of them are subjected to microbial or UV degradation, being suitable only for interior use (Pánek et al., 2014). Furthermore, they can be subjected to leaching or are insoluble in water, thus requiring the use of organic solvents (Yang, 2009).

\subsection{Enzymatic ligation of protectants}

3.3. Enzimsko povezivanje zaštitnih sredstava

Preservatives are often subjected to leaching from wood. This can be prevented by chemical ligation or grafting of preservatives into the wood. Enzymes can catalyse the creation of covalent bonds between wood and preservative (Kudanga et al., 2008; Petrič, 2013; Schubert et al., 2012). In comparison to chemical and physical methods of functionalisation, the use of enzymes is more environmentally friendly due to the reduced use of energy and chemicals (Kudanga et al., 2008). Additionally, the use of enzymes removes the need for expensive catalysts (Slagman et al., 2018). However, poor penetration of the enzymes into the wood poses a problem for the use of enzymatic grafting (Slagman et al., 2018).

Oxidases, including laccases, are used for grafting. Laccases, in contrast to other oxidases, require only oxygen and not hydrogen peroxide for oxidation. Furthermore, the addition of mediators enables oxidation of substances that otherwise do not fit in the active site of laccases (Slagman et al., 2018). Grafting often involves the use of phenolic compounds, although other substrates have been tested as well (Slagman et al., 2018). One of such examples is the use of iodine, which is cheap and is not associated with microbial resistance. Oxidation of iodide $\left(\mathrm{I}^{-}\right)$, which has no antimicrobial activity, to antimicrobial three iodide $\left(\mathrm{I}_{3}^{-}\right)$with laccases and mediators leads to binding of three iodide to aromatic groups of lignin. This provides protection against bacteria, yeast and higher fungi. The use of laccases prevented leaching of the protectant and led to similar effectiveness as a commercial preservative. Furthermore, the lignin degradation by laccases was reported to be 
small (Schubert et al., 2012). Additional improvements can be achieved by the use of anchoring molecules that are covalently bound to the wood and serve as anchors for protectant binding (Kudanga et al., 2008).

\subsection{Surface treatments for increased hydrophobicity}

3.4. Površinska obrada radi povećanja hidrofobnosti

Wood absorbs water both from vapour and liquid state (Glass and Zelinka, 2010). This can lead to swelling and cracking of wood and enables colonisation by pathogens (Burgert et al., 2015; Mai et al., 2004). Cell wall moisture content and hence biological degradation of indoor wood is dependent on the environmental humidity, temperature and ventilation (Mai et al., 2004; Žlahtič and Humar, 2016). Wood with moisture content below $12 \%$ is usually not affected by biological degradation, moisture level of $12-18 \%$ enables infestation by insect, above $18 \%$ enables mould growth, $28-33 \%$ enables growth of higher fungi, and if moisture increases even further, the wood can be affected by bacterial degradation (Mai et al., 2004). Fungal colonisation depends on average moisture over time. Thus applied protectants must prevent both water absorption and allow drying of wood after the exposure to water (Humar and Lesar, 2013).

Many different approaches for reducing the water content of wood have been tested. Lumen of the cells in the wood can be filled up or the surface characteristics of the wood and cell walls may be changed, for example with alkylation of hydrophilic functional groups of lignin, cellulose and hemicellulose (Burgert et al., 2015). Water repellents, such as waxes and oils, including linseed and tung oils, are especially useful as they provide protection against water absorption and at the same time do not seal the wood surface, enabling wood drying (Humar \& Lesar, 2013). Combinations of both oils and waxes were also shown to be beneficial (Žlahtič and Humar, 2016). Effectiveness of repellents depends on the successful impregnation of wood. This is affected by wood permeability and characteristics of the repellent. Performance of repellents thus varies across wood species (Humar and Lesar, 2013). Traditional agents used for decreased water absorption, such as waxes, resins and oils, are subjected to leaching from wood. Thus, it was proposed that laccases should be used for binding of hydrophobic molecules, such as lauryl gallate, on the surface of wood and subsequent creation of a resistant hydrophobic layer (Fernández-Fernández et al., 2015).

Another option is bio-mimicry of super-hydrophobic surfaces that repel water and also have selfcleaning properties. Super hydrophobic surfaces can be created by surface wrinkling, electrospinning, template-based extrusion, photolithography and soft lithography (Chen et al., 2017). General information about these methods is available elsewhere (Bhardwaj \& Kundu, 2010; Meng et al., 2016; Ouyang et al., 2015; Qin et al., 2010; Raoufi et al., 2015). For example, a super-hydrophobic surface pattern imitation of Colocasia esculenta leaf was produced on the wood with soft lithography (Chen et al., 2017).

\section{DECORATION}

\section{DEKORACIJA}

Visual characteristics of wood are highly valued by consumers (Knauf, 2015; Manuel et al., 2015). Besides, bio-based decoration methods can be more environmentally friendly and their application can create unique decorative patterns.

\subsection{Natural dyes}

\subsection{Prirodne boje}

Consumers are becoming interested in natural dyes as production of synthetic dyes is often environmentally unfriendly and their use can be potentially harmful to health (Colak, 2016; Prabhu \& Bhute, 2012; Yeniocak et al., 2015). Different natural dyes are still being tested, such as extracts from pomegranate, red beetroot, and fungi (Colak, 2016; Vega Gutierrez et al., 2016; Yeniocak et al., 2015).

However, there are also downsides of using natural dyes. The final colour can depend on wood composition and may be affected by UV (Yeniocak et al., 2015). Some dyes do not penetrate into the wood and thus colour only the surface (Vega Gutierrez et al., 2016). Furthermore, natural dyes can have poor affinity for binding to the wooden surfaces. Their resistance to discoloration can be improved by the use of mordants, which form complexes with dyes and thus increase their binding to the surface. Metal-based mordants (e.g. iron, aluminium) and vinegar are among commonly tested mordants for colouring of the wood and other natural products. (Colak, 2016; Goktas et al., 2008; Prabhu \& Bhute, 2012; Vega Gutierrez et al., 2016; Yeniocak et al., 2017). However, mordants can lead to colour changes of the dye. Furthermore, some of the mordants, including the metal-based ones, have toxic properties (Prabhu \& Bhute, 2012). Therefore, further research is needed to produce resistant natural dyes.

\subsection{Spalting}

\subsection{Spalting}

Colouring of wood can also be achieved by the use of live organisms, which produce unique patterns and can excrete protective antimicrobial substances. Process of wood colouration based on dye secretion by organisms inhabiting the wood is called spalting. As many consumers desire unique wooden products, spalted wood is highly valued, regardless of the wood species used (Robinson et al., 2012). One of the main concerns is the loss of mechanical properties after spalting. Thus, the use of dense hardwood has been advised (Robinson et al., 2007; Robinson et al., 2012). However, spalted wood does not have importantly reduced mechanical or acoustic properties. Moreover, spalting increases wood permeability, affecting gluing and surface finishing of the products (Robinson et al., $2013 b$ ). Increased permeability can be beneficial, leading to better impregnation (Schubert et al., 2011).

Spalting can result in various patterns and shades, depending on the used microorganism. Zone lines are usually produced by white rot fungi, while ascomycetes produce wood colouring (Robinson et al., 2011a). Spalt- 
ing can be a consequence of excreted dyes with low molecular mass or inoculation of wood with fungi that have pigmented cell walls, leading to zone lines and blue-grey colouring, also known as blue stain (Robinson et al., 2012). Zone lines are easy to produce and can be created by the use of various fungi (Robinson et al., 2011b). Zone lines are often produced as the result of competition, for example between Trametes versicolor and Bjerkandera adusta or Inonotus hispidus and Xylaria polymorpha. Xylaria polymorpha can produce zone lines even when individually inoculated and without application of stressful conditions (Robinson, 2012; Robinson et al., 2012). Blue stain of sapwood is produced by fungi from Ophiostoma genera that are in nature transmitted by bark beetles. However, blue stain wood is less popular among consumers (Robinson et al., 2013b). Pink stain is produced by naphthoquinone of Arthrographis cuboidea and xylindein of Scytalidium cuboideum, also on conifers and bamboo. However, Scytalidium cuboideum produces zone lines instead of pink pigmentation when grown together with other fungi. Bright blue-green pigmentation arises due to xylindein produced by Chlorociboria genus on poplar wood. Yellow stain is produced by quinones of Scytalidium ganodermophthorum (Mai et al., 2004; Robinson, 2012; Robinson et al., 2013a; Robinson et al., 2013b; Vega Gutierrez et al., 2016). Furthermore, wood can be inoculated with a mixture of fungi or inoculated more than once with different fungi (Robinson et al., 2013b). For example, increased visibility of spalting can be achieved by initial bleaching of wood with white rot fungi, sterilisation and subsequent inoculation with the desired spalting fungi. However, sterilisation can only be used for small wood pieces, as increased volume leads to overly prolonged sterilisation times (Robinson et al., 2012). Nevertheless, this method can still be used for production of "furniture jewellery".

Spalting can be adopted at the industrial level (Robinson et al., 2011a). It was tested by Robinson et al. (2013a), who discovered that specific combinations of Scytalidium cuboideum, Xylaria polymorpha and Trametes versicolor produce the best zone lines. In order to achieve spalting fungi must be able to penetrate into the wood and grow inside it (Robinson et al., 2012; Vega Gutierrez et al., 2016). At the industrial level it is important to choose the right inoculation method, depending on the fungi (Robinson et al., 2013a). Additionally, prior sterilisation can increase the pigmentation (Robinson et al., 2011b). Growth of the fungi is then stopped before the loss of mechanical properties of wood (Robinson et al., 2011a). Fungal growth and spalting depend on may parameters (Robinson et al., 2011a), including wood species, which must be chosen based on the desired pigmentation. For example, sugar maple can be spalted by a broad range of fungi, while some wood species can be spalted with only certain fungi or none at all (Robinson et al., 2011a). Antifungal substances in wood can importantly reduce fungal growth, while some stressors may increase the spalting. Sugar content also affects the spalting (Robinson et al., 2011a). However, the success of spalting varies greatly and thus reliable combinations of wood and fungi should be chosen (Robinson, 2012).

\section{NEW WOODEN MATERIALS}

\section{NOVI DRVNI MATERIJAL}

Wood has low density, good mechanical properties, and is relatively inexpensive and sustainable. Thus, new approaches for widening the range of applications of wood are being investigated (Burgert et al., 2015; Gan et al., 2017; Li et al., 2018). However, the heterogeneity of wood decreases the reliability of its mechanical properties and reduces the control over the process of wood functionalisation (Frey et al., 2018). Functional wood based materials were described in more detail by Burgert et al. (2015).

\subsection{Wood densification}

\subsection{Ugušćivanje drva}

Density is one of the main factors affecting mechanical properties of wood. Wood densification can increase homogeneity and mechanical properties, while retaining the ordered structure of wood. (Frey et al., 2018). It increases hardness and surface abrasion resistance and can lead to colour changes (Cruz et al., 2018; Sozbir and Bektas, 2017). Densification can be used to improve mechanical properties of wood of low-density species. Therefore, hardwood species can be replaced by low-density species in applications such as table tops and floors (Sozbir and Bektas, 2017). Process of wood surface densification has been already industrialised (Sandberg et al., 2017). On the other hand, lightweight wooden materials reduce economic and ecological burden of furniture transport (Iejavs and Spulle, 2016) and have potential for multifunctional furniture.

Wood densification process is comprised of wood softening by moistening and heat treatment, followed by compression leading to collapse of cell walls, and is finished by locking the wood in compressed state by drying and cooling. Fixation of the compressed state can be further improved by impregnation with adhesives (Sandberg et al., 2017; Sozbir \& Bektas, 2017). The process is usually applied only to the surface of the wood, leading to greater usage efficiency of the material, easier production and better mechanical properties for certain applications (Sandberg et al., 2017). Uneven compression enables production of wood with gradual variation in density and stiffness (Frey et al., 2018). Furthermore, chemical composition of wood importantly affects the mechanical properties of densified wood, as was shows on Pinus radiata (Cruz et al., 2018). Delignification can be used to ease the curving or twisting of wood (Frey et al., 2018).

\subsection{Wood functionalisation and hybrid materials}

\subsection{Funkcionalizacija drva i hibridni materijali}

Wood can be functionalised to induce changes in its property profile. For example, incorporation of mineral particles into the wood can increase strength, fracture resistance, hardness, and stiffness (Burgert et al., 2015). Furthermore, changes in magnetic, conductor and optical properties could be used to extend the range of applications of wood into electrotechnical industry (Burgert et al., 2015; Gan et al., 2017; Li et al., 2018). Transparent wood has already been produced; howev- 
er, its optical properties are still greatly dependent on thickness and any subsequent compression of the material. It has potential for the use in buildings due to its low density and light transmittance as well as reduced heath conductivity and frailness in comparison to glass (Li et al., 2018). Furthermore, transparent wood can be functionalised with luminescent properties (Gan et al., 2017; Li et al., 2018).

Transparent wood can be manufactured by delignification or removal of chromophores followed by impregnation with polymer with refractive index matching the wood. The polymer fills pores in the wood that would otherwise lead to scattering of the light (Gan et al., 2017; Li et al., 2018). However, delignification is time consuming and can pose a burden for the environment (Li et al., 2018). Furthermore, functionalisation of bulk wood is challenging. This could potentially be improved by separation of wood into fibres, which would be functionalised and then re-aligned into the wooden structure (Frey et al., 2018). For example, Gradwell et al. (2004) used soluble pullulan as a model for lignin. Pullulan adsorbed to the cellulose surface leads to selfassembly (Gradwell et al., 2004).

Wood can also be used to produce hybrids with synthetic or inorganic materials. The main benefit of wood incorporation is its ordered structure (Burgert et al., 2015; Croitoru et al., 2018). For example, wood can serve as a framework for production of synthetic materials in which it is otherwise challenging to produce an ordered structure. This has potential for optical implications (Burgert et al., 2015). Furthermore, it was proposed that wood may be useful for substituting synthetic polymers (Li et al., 2018). Wooden fibres incorporated into plastics are already being used in the industry. However, protectants used in such materials often pose health risks (Croitoru et al., 2018). Thus, ionic liquids, substances composed entirely from ions with melting point below $100{ }^{\circ} \mathrm{C}$ (Lei et al., 2017), were proposed as a substitute (Croitoru et al., 2018).

\section{MARKETING POTENTIAL}

\section{MARKETINŠKI POTENCIJAL}

Innovations in the wood industry promise better visual and mechanical properties as well as reduced burden for the environment. This has potential for marketing, as consumers already associate wood with wellbeing, aesthetics and environmental friendliness (Manuel et al., 2015). Uniqueness is highly valued among consumers, especially when purchasing items with hedonistic rather than strictly functional role (Reich et al., 2017). Thus, "furniture jewellery" applications may have a good potential. Furthermore, the lifespan of furniture design is shortening (Scholz and Decker, 2007) and thus novel wood processing technologies may bring about innovations desired by consumers.

Environmental friendliness is important decision factor for many consumers, as shown by a Brazilian study, in which consumers were prepared to pay more for environmentally friendly furniture (de Medeiros et al., 2016). Environmental friendliness can be achieved by the reduced use of energy and resources, recycling and waste reduction, and by following the principles of sustainable development (Huang et al., 2012). However, main attributes in the choice of furniture are still elsewhere, including: comfort, design, (de Medeiros et al., 2016; Holopainen et al., 2014), brand, price (Caia et al., 2017), and durability (Holopainen et al., 2014).

Marketing for new technologies can be challenging. The degree of newness in a product must be balanced, as consumers can distrust the usability of the product or are disheartened by their own uncertainty about the proper maintenance of the item (Cojocaru et al., 2013). Additionally, it has been shown in a Chinese study that eco-labels are often distrusted and that many consumers are unable to distinguish between ordinary and green furniture (Caia et al., 2017). Thus, not only the development of new technologies, but also research in their marketing must be conducted.

\section{CONCLUSION \\ 7. ZAKLJUČAK}

The use of biotechnology, natural products or nature-inspired methods has great potential in furniture industry. These methods can lead to production of ecofriendly wood with changed physical properties and unique visual characteristics. Here presented methods may thus inspire the development of new wooden furniture products.

In general, most investigated methods include the use of enzymes, live organisms, and natural products. Additionally, production of functionalised wood and hybrid materials is also gaining importance. Nevertheless, many applications are still not developed at the industrial level. Common drawbacks include complexity or unreliability of the methods, inadequate mechanical properties or dimensional stability of the final products, and high costs. Thus, further research on both laboratory and pilot scale is required.

\section{REFERENCES}

\section{LITERATURA}

1. Bhalerao, R.; Nilsson, O.; Sandberg, G., 2003: Out of the woods: forest biotechnology enters the genomic era. Current Opinion in Biotechnology, 14 (2): 206-213. 10.1016/ s0958-1669(03)00029-6.

2. Bhardwaj, N.; Kundu, S. C., 2010: Electrospinning: a fascinating fiber fabrication technique. Biotechnol Adv, 28 (3): 325-347.

3. Bruce, A.; King, B., 1991: Decay Resistance of Wood Removed from Poles Biologically Treated with Trichoderma. Holzforschung, 45: 307-311.

4. Burgert, I.; Cabane, E.; Zollfrank, C.; Berglund, L., 2015: Bio-inspired functional wood-based materials - hybrids and replicates. International Materials Reviews, 60 (8): 431-450.

5. Caia, Z.; Xieb, Y.; Aguilarc, F. X., 2017: Eco-label credibility and retailer effects on green product purchasing intentions. Forest Policy and Economics, 80: 200-208.

6. Chen, Y.; Wang, H.; Yao, Q.; Fan, B.; Wang, C.; Xiong, Y.; Jin, C.; Sun, Q., 2017: Biomimetic taro leaf-like films decorated on wood surfaces using soft lithography for 
superparamagnetic and superhydrophobic performance. J Mater Sci, 52: 7428-7438.

7. Cojocaru, M. G.; Thille, H.; Thommes, E.; Nelson, D.; Greenhalgh, S., 2013: Social influence and dynamic demand for new products. Environmental Modelling \& Software, 50: 169-185.

8. Colak, M., 2016: Determination of antifungal and antibacterial activities of natural dye of pomegranate skin (Punica granatum L.) implemented on wooden materials. Wood Research, 61 (5): 709-718.

9. Croitoru, C.; Varodi, A. M.; Timar, M. C.; Roata, I. C.; Stanciu, E. M.; Pascu, A., 2018: Wood-plastic composites based on HDPE and ionic liquid additives. Journal of Materials Science, 53 (6): 4132-4143.

10. Cruz, N.; Bustos, C. A.; Aguayo, M. G.; Cloutier, A.; Castillo, R., 2018: Impact of the Chemical Composition of Pinus radiata Wood on its Physical and Mechanical Properties Following Thermo-Hygromechanical Densification. 13 (2): 15.

11. de Medeiros, J. F.; Ribeiro, J. L. D.; Cortimiglia, M. N., 2016: Influence of perceived value on purchasing decisions of green products in Brazil. Journal of Cleaner Production, 110: 158-169.

12. Fackler, K.; Kuncinger, T.; Ters, T.; Srebotnik, E., 2008: Laccase-catalyzed functionalization with 4-hydroxy3 -methoxybenzylurea significantly improves internal bond of particle boards. Holzforschung, 62: 223-229.

13. Felby, C.; Hassingboe, J.; Lund, M., 2002: Pilot-scale production of fiberboards made by laccase oxidized wood fibers: board properties and evidence for crosslinking of lignin. Enzyme and Microbial Technology, 31 (6): 736-741. 10.1016/s0141-0229(02)00111-4.

14. Ferdosian, F.; Pan, Z. H.; Gao, G. C.; Zhao, B. X., 2017: Bio-Based Adhesives and Evaluation for Wood Composites Application. Polymers, 9 (2): 70. 10.3390/polym 9020070.

15. Fernández-Costas, C.; Palanti, S.; Sanromán, M. A.; Moldes, D., 2017: Enzymatic grafting of kraft lignin as a wood bio-protection strategy. Part 2: effectiveness against wood destroying basidiomycetes. Effect of copper entrapment. Holzforschung, 71 (9): 689-695.

16. Fernández-Fernández, M.; Sanromán, M. A.; Moldes, D., 2015: Wood Hydrophobization by Laccase-Assisted Grafting of Lauryl Gallate. Journal of Wood Chemistry and Technology, 35 (2): 156-165.

17. Frey, M.; Widner, D.; Segmehl, J. S.; Casdorff, K.; Keplinger, T.; Burgert, I., 2018: Delignified and Densified Cellulose Bulk Materials with Excellent Tensile Properties for Sustainable Engineering. ACS Appl Mater Interfaces, 10 (5): 5030-5037. 10.1021/acsami.7b18646.

18. Gabrič, M. V.; Pohleven, F., 2014: Laccase Application for Upgrading of Lignocellulose Fibers. Drvna industrija, 66 (1): 49-55.

19. Gan, W.; Xiao, S.; Gao, L.; Gao, R.; Li, J.; Zhan, X., 2017: Luminescent and Transparent Wood Composites Fabricated by Poly(methyl methacrylate) and $\gamma$-Fe2O3@ YVO4:Eu3+ Nanoparticle Impregnation. ACS Sustainable Chem. Eng., 5 (5): 3855-3862.

20. Glass, S.; Zelinka, S., 2010: Moisture Relations and Physical Properties of Wood. In: Wood handbook - Wood as an engineering material. Centennial Edition, General Technical Report FPL-GTR-190, Chapter: 4. Publisher: United States Department of Agriculture - Forest Service - Forest Products Laboratory. Robert J. Ross (ed.).

21. Goktas, O.; Emin, M.; Mehmetyeniocak, D.; Ozen, E., 2008: Determination of the color stability of an environmentally friendly wood stain derived from laurel (Laurus nobilis L.) leaf extracts under UV exposure. Forest Products Journal, 58: 77-80.

22. Gradwell, S. E.; Renneckar, S.; Esker, A. R.; Heinze, T.; Gatenholm, P.; Vaca-Garcia, C.; Glasser, W., 2004: Sur- face modification of cellulose fibers: towards wood composites by biomimetics. C R Biol, 327 (9-10): 945-953.

23. Holopainen, J. M.; Häyrinen, L.; Toppinen, A., 2014: Consumer value dimensions for sustainable wood products: results from the Finnish retail sector. Scandinavian Journal of Forest Research, 29 (4): 378-385.

24. Huang, K.; Zhang, Z.; Tao, Z.; Liu, H., 2012: Study on Key technologies of the Green Furniture Design Applied Mechanics and Materials, 224: 208-211.

25. Humar, M.; Lesar, B., 2013: Efficacy of linseed- and tung-oil-treated wood against wood-decay fungi and water uptake. International Biodeterioration \& Biodegradation, 85: 223-227. https://doi.org/10.1016/j.ibiod.2013.07.011.

26. Iejavs, J.; Spulle, U., 2016: Cellular Wood Material Properties - Review. Drewno, 59 (189): 5-18.

27. Jin, L.; Seilers, T.; Schultz, T. R., Jr.; Nicholas, D. D., 1990: Utilization of Lignin Modified by Brown-Rot Fungi. Holzforschung, 44: 207-210.

28. Jung, S. J.; Kim, N. K.; Lee, D. H.; Hong, S. I.; Lee, J. K., 2018: Screening and Evaluation of Streptomyces Species as a Potential Biocontrol Agent against a Wood Decay Fungus, Gloeophyllum trabeum. Mycobiology, 46 (2): 138-146. 10.1080/12298093.2018.1468056.

29. Knauf, M., 2015: Understanding the consumer: Multimodal market research on consumer attitudes in Germany towards lightweight furniture and lightweight materials in furniture design. Eur. J. Wood Prod., 73: 259-270.

30. Kudanga, T.; Prasetyo, E. N.; Sipilä, J.; Nousiainen, P.; Widsten, P.; Kandelbauer, A.; Nyanhongo, G. S.; Guebitz, G., 2008: Laccase-Mediated Wood Surface Functionalization. Eng. Life Sci., 8 (3): 297-302.

31. Lei, Z.; Chen, B.; Koo, Y. M., 2017: Introduction: Ionic Liquids. Chemical Reviews, 117: 6633-6635.

32. Li, Y.; Fu, Q.; Yang, X.; Berglund, L., 2018: Transparent wood for functional and structural applications. Philos Trans A Math Phys Eng Sci, 376 (2112). 10.1098/ rsta.2017.0182.

33. Liu, D.; Chen, H.; Chang, P. R.; Wub, Q.; Li, K.; Guan, L., 2010: Biomimetic soy protein nanocomposites with calcium carbonate crystalline arrays for use as wood adhesive. Bioresource Technology, 101: 6235-6241.

34. Mai, C.; Kues, U.; Militz, H., 2004: Biotechnology in the wood industry. Appl Microbiol Biotechnol, 63 (5): $477-$ 94. 10.1007/s00253-003-1411-7.

35. Manuel, A.; Leonhart, R.; Broman, O.; Becker, G., 2015: Consumers' perceptions and preference profiles for wood surfaces tested with pairwise comparison in Germany. Annals of Forest Science, 72: 741-751.

36. Meng, J.; Xie, J.; Han, X.; Lu, C., 2016: Surface wrinkling on polydopamine film. Applied Surface Science, 371: 96-101.

37. Ouyang, S.; Xie, Y.; Wang, D.; Zhu, D.; Xin Xu; Tan, T.; Fong, H. H., 2015: Surface Patterning of PEDOT: PSS by Photolithography for Organic Electronic Devices. Journal of Nanomaterials, 2015.

38. Ozen, E.; Yeniocak, M.; Goktas, O.; Alma, M. H.; Yilmaz, F., 2014: Antimicrobial and Antifungal Properties of Madder Root (Rubia tinctorum) Colorant Used as an Environmentally-Friendly Wood Preservative. BioResources, 9 (2): 1998-2009.

39. Pánek, M.; Reinprecht, L.; Hulla, M., 2014: Ten Essential Oils for Beech Wood Protection - Efficacy Against Wood-destroying Fungi and Moulds and Effect on Wood Discoloration. BioResources, 9 (3).

40. Petrič, M., 2013: Surface Modification of Wood: A Critical Review. Rev. Adhesion Adhesives, 1 (2): 216-247. 10.7569/RAA.2013.097308.

41. Prabhu, K. H.; Bhute, A. S., 2012: Plant based natural dyes and mordnats: A Review. J. Nat. Prod. Plant Resour., 2 (6): 649-664. 
42. Qin, D.; Xia, Y.; Whitesides, G. M., 2010: Soft lithography for micro- and nanoscale patterning. Nat Protoc., 5 (3): 491-502.

43. Raoufi, M.; Das, T.; Schoen, I.; Vogel, V.; Brüggemann, D.; Spatz, J. P., 2015: Nanopore Diameters Tune Strain in Extruded Fibronectin Fibers. Nano Lett, 15 (10): 6357-6364.

44. Reich, T.; Kupor, D. M.; Smith, R. K., 2017: Made by Mistake: When Mistakes Increase Product Preference. Journal of Consumer Research, 44 (5): 1085-1103.

45. Robinson, S. C.; Richter, D. L.; Laks, P. E., 2007: Colonization of sugar maple by spalting fungi. Forest Products Journal, 57 (4): 24-32.

46. Robinson, S. C.; Tudor, D.; Cooper, P. A., 2011a: Wood preference of spalting fungi in urban hardwood species. International Biodeterioration \& Biodegradation, 65: 1145-1149.

47. Robinson, S. C.; Tudor, D.; Cooper, P. A., 2011b: Feasibility of using red pigment producing fungi to stain wood for decorative applications. Can. J. For. Res., 41: 1722-1728.

48. Robinson, S. C., 2012: Developing fungal pigments for "painting" vascular plants. Appl Microbiol Biotechnol, 93: 1389-1394.

49. Robinson, S. C.; Tudor, D.; Cooper, P. A., 2012: Utilizing pigment-producing fungi to add commercial value to American beech (Fagus grandifolia). Appl Microbiol Biotechnol, 93: 1041-1048.

50. Robinson, S. C.; Tudor, D.; Hipson, S.; Snider, H.; Ng, S.; Korshikov, E.; Cooper, K. A., 2013a: Methods of inoculating Acer spp., Populus tremuloides and Fagus grandifolia logs for commercial spalting applications. J Wood Sci, 59: 351-357.

51. Robinson, S. C.; Tudor, D.; MacDonald, G.; Mansourian, Y.; Cooper, P. A., 2013b: Repurposing mountain pine beetle blue wood for art through additional fungal colonization. International Biodeterioration \& Biodegradation, 85: 372-374.

52. Sajitha, K. L.; Dev, S. A.; Florence, E. J., 2018: Biocontrol potential of Bacillus subtilis B1 against sapstain fungus in rubber wood. European Journal of Plant Pathology, 150 (1): 237-244. 10.1007/s10658-017-1272-z.

53. Sandberg, D.; Kutnar, A.; Mantanis, G., 2017: Wood modification technologies - a review. iForest - Biogeosciences and Forestry, 10 (6): 895-908. 10.3832/ifor2380-010.

54. Scholz, S. W.; Decker, R., 2007: Measuring the impact of wood species on consumer preferences for wooden furniture by means of the Analytic Hierarchy Process. Forest Products Journal, 57 (3): 23-28.

55. Schubert, M.; Volkmer, T.; Lehringer, C.; Schwarze, F. W. M. R., 2011: Resistance of bioincised wood treated with wood preservatives to blue-stain and wood-decay fungi. International Biodeterioration \& Biodegradation, 65: 108115.

56. Schubert, M.; Engel, J.; Thony-Meyer, L.; Schwarze, F. W.; Ihssen, J., 2012: Protection of wood from microorganisms by laccase-catalyzed iodination. Appl Environ Microbiol, 78 (20): 7267-7275. 10.1128/AEM.01856-12.

57. Schwarze, F.; Schubert, M., 2017: Bioengineering of Value-Added Wood Using the White Rot Fungus Physisporinus vitreus. Nr. Springer International Publishing Ag: Cham.

58. Slagman, S.; Zuilhof, H.; Franssen, M. C. R., 2018: Laccase-Mediated Grafting on Biopolymers and Synthetic Polymers: A Critical Review. Chembiochem, 19 (4): 288311. 10.1002/cbic.201700518.

59. Smith, J. E., 2009: Biotechnology. Nr. 5. Cambridge University Press: Cambridge.

60. Sozbir, G. D.; Bektas, I., 2017: The Effect of Heat Modification and Densification on Physical Properties of Poplar Wood. Drvna industrija, 68 (4): 315-321. 10.5552/drind. 2017.1719.

61. Susi, P.; Aktuganov, G.; Himanen, J.; Korpela, T., 2011: Biological control of wood decay against fungal infection.
Journal of Environmental Management, 92 (7): 16811689. 10.1016/j.jenvman.2011.03.004.

62. Tascioglu, C.; Yalcin, M.; Sen, S.; Akcay, C., 2013: Antifungal properties of some plant extracts used as wood preservatives. International Biodeterioration \& Biodegradation, 85: 23-28. https://doi.org/10.1016/j.ibiod.2013.06.004.

63. Thaler, N.; Lesar, B.; Kariz, M.; Humar, M., 2012: Bioincising of Norway spruce wood using wood inhabiting fungi. International Biodeterioration \& Biodegradation, 68: 51-55. 10.1016/j.ibiod.2011.11.014.

64. Umorina, Z., 2017: Peculiarities of Natural Technology Application in Architecture. International Conference on Construction, Architecture and Technosphere Safety, 262. 10.1088/1757-899x/262/1/012125.

65. van Nieuwenhuijzen, E. J.; Houbraken, J. A. M. P.; Meijer, M.; Adan, O. C. G.; Samson, R. A., 2016: Aureobasidium melanogenum: a native of dark biofinishes on oil treated wood. Antonie van Leeuwenhoek, 109 (5): 661-683. 10.1007/s10482-016-0668-7.

66. Vega Gutierrez, S. M.; Vega Gutierrez, P. T.; Godinez, A.; Pittis, L.; Huber, M.; Stanton, S.; Robinson, S. C., 2016: Feasibility of Coloring Bamboo with the Application of Natural and Extracted Fungal Pigments. Coatings, 6 (37). 10.3390/coatings6030037.

67. Wang, S. Y.; Su, D. Z.; Zhu, S. F., 2016: A Comparative Study on Life Cycle Assessment of Typical Wood base Furniture. Nr. 63. Atlantis Press: Paris, pp. 634-640.

68. Wang, Y.; Chang, J.; Morrell, J. J.; Freitag, C. M.; Karchesy, J. J., 2012: An integrated approach using Bacillus subtilis B26 and essential oils to limit fungal discoloration of wood. BioResources, 7 (3): 3132-3141.

69. Widsten, P.; Kandelbauer, A., 2008: Laccase applications in the forest products industry: A review. Enzyme and Microbial Technology, 42 (4): 293-307. 10.1016/j.enzmictec.2007.12.003

70. Yang, D. Q., 2009: Potential utilization of plant and fungal extracts for wood protection. Forest Prod. J., 59 (4): 97-103.

71. Yeniocak, M.; Goktas, O.; Colak, M.; Ozen, E.; Ugurlu, M., 2015: Natural coloration of wood material by red beetroot (Beta vulgaris) and determination color stability under UV exposure. Maderas. Ciencia y tecnología, 17 (4): 711-722.

72. Yeniocak, M.; Goktas, O.; Aliyazicioglu, S.; Colak, M.; Yeniocak, S.; Ozen, E.; Ugurlu, M., 2017: Determination of the Effect of Liquid Glass $\left(\mathrm{SiO}_{2}\right)$ on Color Stability of Wood Stained by Natural Dyes. Drvna industrija, 68: 351357. 10.5552/drind.2017.1707.

73. Zhou, J.; Yang, T.; Mei, Y.-Z.; Kang, L.; Dai, C.-C., 2014: Laccase production by Phomopsis liquidambari B3 cultured with food waste and wheat straw as the main nitrogen and carbon sources. Journal of the Air \& Waste Management Association, 64 (10): 1154-1163. 10.1080/ 10962247.2014 .930077$.

74. Žlahtič, M.; Humar, M., 2016: Influence of Artificial and Natural Weathering on the Moisture Dynamic of Wood. BioResources, 12 (1):117-142. 10.15376/biores.12.1. 117-142.

75. $* * * 2004$. International Wooden Furniture Markets: A review. International Trade Centre UNCTAD/WTO and International Tropical Timber Organization, Geneva.

\section{Corresponding address:}

\section{Prof. JASNA HROVATIN, PhD}

Faculty of Design

University of Primorska

Prevale 10, 1236 Trzin, SLOVENIA

e-mail: jasna.hrovatin@fd.si 